\title{
The Application of Fuzzy Inference System (FIS) to Determine the Employee Additional Salary
}

\author{
Mujiono Sadikin, S. K. Purwanto, and Darminto
}

\begin{abstract}
The increasing of employee salary is one of the mechanisms to maintain the good employee performance. The decision of periodic additional salary for a certain employee is the difficult task even in some cases this is a sensitive issue. To minimize such as those problems, the fair additional salary computation performed by system can be chosen as the way out. The study presents the application of fuzzy inference system (FIS) to determine the additional salary computation. This study uses the real dataset collected from a local drinking water distribution company. The experiment results confirm that the method is feasible to be applied for this purpose. This feasibility conclusion is supported by the little deviation between manual computation results compared to FIS. For almost all cases, the FIS provides more detail results.
\end{abstract}

Index Terms - Employee Appraisal, Additional Salary, Employee Performance, Decision Support System, FIS, Fuzzy Logic.

\section{INTRODUCTION}

Human resources are the most valuable assets to any business organizations. The quality of human resources is the main role to support the company growth. Thus, the employee performance is very important parameter to decision makers and the process of employee performance appraisal is one of company process keys. The goal of performance appraisal is to capture the contribution quality - in term of capability and professionalism - of certain employee to the company[1]. The main objective of the appraisal is to identify the potentiality of employee performance improvements. There are many ways can be taken to improve the employee performance. One of those ways is salary addition. The good mechanism to increase the employee salary is based on a certain assessment. The assessment is performed to guarantee the fairness of the salary increasing to each employee [2].

The employee performance criteria are one of the parameters which contains ambiguity and fuzziness [3]. By nature, these criteria could not be approached by clearly true or false logical proposition. In many cases, the employee salary addition decision is determined subjectively, and the HR division has no fair parameters of decision process. This study is performed to overcome the decision weakness by to propose the fuzzy logic approach. The study is conducted in a private company located in Jakarta Indonesia. The results of the study confirm that the fuzzy approach is capable to achieve the more accurate decision compared to the conventional computation performed by the HR Division.

The rest of the paper is organized as follows. Section two

Submitted on May 18, 2021.

Published on June 09, 2021.

Mujiono Sadikin, Universitas Mercu Buana, Indonesia.

(e-mail: mujiono.sadikin@mercubuana.ac.id) discusses the related study regarding the discussed topic. In the next section, section tree, it presented the material and method used in the study. The data processing and computational mechanism are presented in the section four. The experiment results and its discussion are explained in the fifth section, whereas the last section presents the conclusion and the future work related to the subject.

\section{RELATED WORK}

As the importance of the employee to the organization, there are many studies relates to the human resources management purposes have been performed. These HR management purposes such as: selection and promotion, employee performance appraisal, and employee welfare related decision making as well [3]-[8]. Many of those studies utilize fuzzy as the main approach technique. Aries Muthohar et al performed the study of medical employee performance by utilizing the fuzzy logic algorithm [8]. The employee attributes used to evaluate their performance are tangibility, reliability, responsiveness, assurance, and empathy. To those variables are applied defuzzyfication process that provides the performance evaluation value of 84,9 as the indicators of the employee good performance. The other study as presented in [9] uses logical fuzzy applied to four input parameters i.e., way of work, politeness, attitude and appearances. Each of the input values of those parameters is: $70,75,89$ and 80 and the results of defuzzyfication process is 74.99 .

D'Urso et al, as presented in the publication [5], study the MCDM (Multi Criteria Decision Making) in fuzzy logic to support decision making that able to accommodate many complex criteria. The author proposes the fuzzy logic hierarchy method to overcome some issues associated with the uncertainty and the vagueness of specific decisions in very complex and multi-criteria frameworks. Based on the experiment results, author conclude that the method can be improved to get the optimum solution.

Another interesting of fuzzy variant applied in the human resources management area is ANFIS (Adaptive Neural Fuzzy Inference System) which is proposed by Krichevky et al [10]. In supporting the decision making on employee candidate selection, the author proposed a multi layers decision making system. The multi layers configuration is combination of $\mathrm{NN}$ and fuzzy logic. The intermediate output of this architectures is the regression equation which connects the candidate quality with his/her characteristics.

\footnotetext{
S. K. Purwanto, Universitas Esa Unggul, Indonesia.

(e-mail: purwanto@esaunggul.ac.id)

Darminto, Universitas Mercu Buana, Indonesia.

(e-mail: 41513120034@student.mercubuana.ac.id).
} 
Mamdani and sugeno, the others type of fuzzy logics, have also been proposed to support the decision-making process in manager candidate selection. The study is performed by $\mathrm{M}$. Tinkir et al [11] which use the First 500 big industrial organization as the case study environment. The study results revealed that the various fuzzy approaches are considerable to be applied to achieve more precision decision results in human resources management which commonly involves many complex variables.

The utilization of fuzzy logic is also performed by Dedi et al [12]. In the study, fuzzy logic is used to review the employee's performances of a famous retail company in Indonesia has huge branches. The appraisal is based on two criteria: personal and job related. The result of the study shows that by using the input parameter value of personal of 66.7 and job-related value of 60 , the final result is 68.3 as the fuzzy set of defuzzyfication process. The competency evaluation 3600 feedback using fuzzy is presented in [13]. By using fuzzy logic, the author shows its advantages in handling the ambiguity and subjectivity, as the evaluator can assign words to express a qualification. The other multisource feedback (3600) study based on fuzzy logic is also proposed by G. Meenakshi [4].

Another fuzzy logic concept applied to student appraisal is as performed by E. Sakthivel et al [14] and Shilpa N. Ingoley et al [15]. Both of studies utilize the fuzzy logic, which is compared to the classical method. The studies confirm that the value resulted by the fuzzy logic is close to the classical method with the accuracy level is $90 \%$. As the simplicity of its formula, classical method is more suitable in this case compared to the fuzzy logic method.

There are many others study utilizes fuzzy logic to do such appraisal. S. Pavani et al [16] use fuzzy logic to assist the evaluation process of teacher performance. The environmental performance appraisal of an organization decision support system based on fuzzy logic approach is proposed by [17]. The approach is claimed to offer many advantages such as the flexibilities, the simplicity of its computation, and it is ideal system when it faced with a series of sub-decisions where available data is based on vagueness, uncertainty, and opinion.

\section{MATERIAL AND METHOD}

\section{A. Dataset}

The data set is collected from a certain company which focus business is in drinking water distribution. The data are used by company management to determine the percentage of employee salary addition in the year of 2018. We use the same data as the input of the proposed fuzzy system, and then it is compared to the manually processed results. Each instant of data consists of five attributes: employee_id, employee_name, loyalties, responsibilities, value of lateness and working speed value.

Of those five attributes, we use the three attributes as the appraisal criteria: loyalties, Lateness, and working speed. The value of those criteria is ranging from 0 to 10 . The loyalties and responsibilities will be 0 for the worst and 10 for the best. The employee who never comes late will be assigned the score of 0 for the lateness criteria, and the score of 10 for whom the most frequent come late. While the working speed criteria is 0 for who work slowest, and 10 for the fastest. The other component as the input of defuzzyfication process is the rule of appraisal. The rule of the appraisal while determines the output based on the attribute's value. We define 27 rules, and some of these rules are presented in Table I.

TABLE I: SAMPLE OF FUZZY RULE

\begin{tabular}{cccc}
\hline \hline Loyalty \& Resp. & Lateness & $\begin{array}{c}\text { Working } \\
\text { Speed }\end{array}$ & $\begin{array}{c}\text { Salary } \\
\text { Additional }\end{array}$ \\
\hline Low & No & Slow & Low \\
Low & No & Intermediate & Low \\
Low & No & Fast & Low \\
Intermediate & No & Slow & Low \\
Intermediate & No & Intermediate & Low \\
Intermediate & No & Fast & High \\
High & Frequent & Slow & Standard \\
High & Frequent & Intermediate & Standard \\
High & Frequent & Fast & Standard \\
\hline
\end{tabular}

\section{B. Experiment Stages}

As presented in Fig. 1, the stages of experiment in this study consist of 3 phases: the data representation, membership model development, and data processing. The activities performed in data representation stage are data collection and data cleansing. The data cleansing performed to eliminate any invalid data, incomplete data or the data contain ambiguities. The next stage is the model development. In this stage it is developed membership model function of each appraisal criteria and its output as well. In the last stage, we perform data processing by applying the fuzzy logic formula.

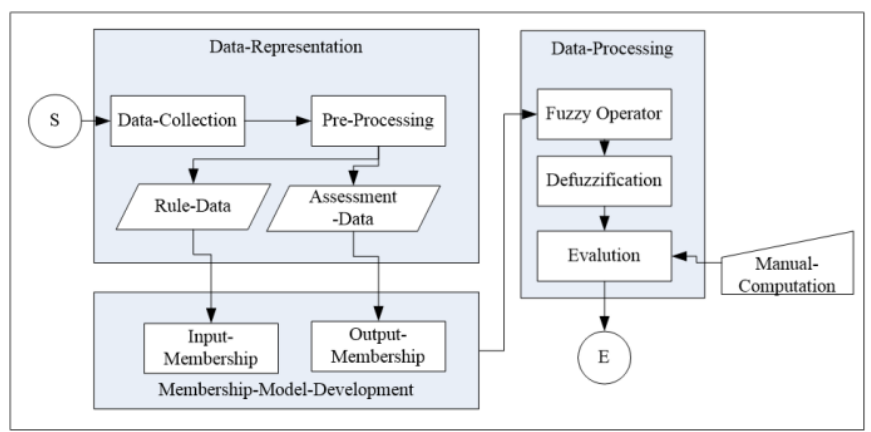

Fig. 1. Experiments Stage.

The main goal of the fuzzy logic method is to map the input space into output space by using the IF-THEN rules. The mapping is known as the Fuzzy Inference System (FIS). In the fuzzy system, it has to be defined the rule before the inference fuzzy system is applied. In general the fuzzy system consists of tree component: fuzzyfication, inference and defuzzyfication [18], as illustrated in Fig. 2.

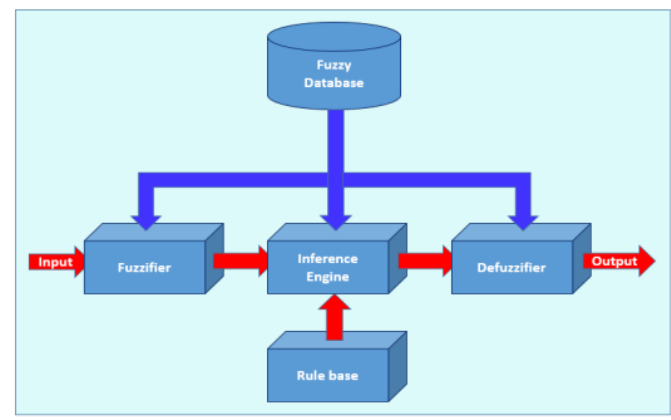

Fig. 2. Fuzzy Inference Structure. 


\section{Data Preprocessing}

As presented in Fig. 1, the stages of experiment in this study consist of 3 phases: the data representation, membership model development, and data processing. The activities performed in data representation stage are data collection and data cleansing. The data cleansing performed to eliminate any invalid data, incomplete data or the data contain ambiguities. The next stage is the model development. In this stage it is developed membership model function of each appraisal criteria and its output as well. In the last stage, we perform data processing by applying the fuzzy logic formula.

Some samples of data collected are presented in Table I. Based on the three criteria, the company determines the additional of employee salary by percentage. The company policy regarding the additional salary is ranging from $5 \%$ to $25 \%$ of the current salary. To overcome the problem by the FIS computation methods, some steps are performed. Those steps are to develop the fuzzy set and fuzzy input, to apply the fuzzy operator, to apply the implication function, and to compose all of the output and defuzzyfication.

\section{To Develop the Fuzzy Set \& Fuzzy Input}

There are three input parameters of the data, ie. Loyalty \& responsibility \{low, lntermediate, high); Lateness \{none, rare, frequent\}; and work speed \{slow, intermediate, and fast $\}$. Thus, we will have three membership functions (MF) as presented in Fig. 3, 4, and 5.

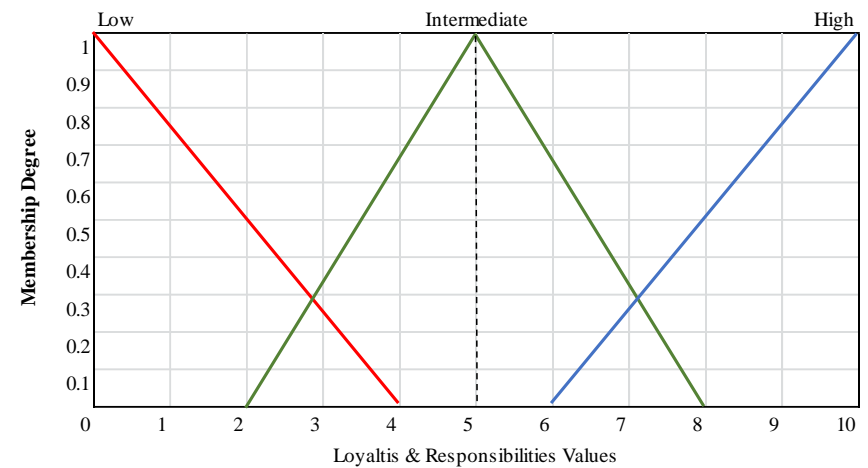

Fig. 3. MF of Loyalty \& Responsibility.

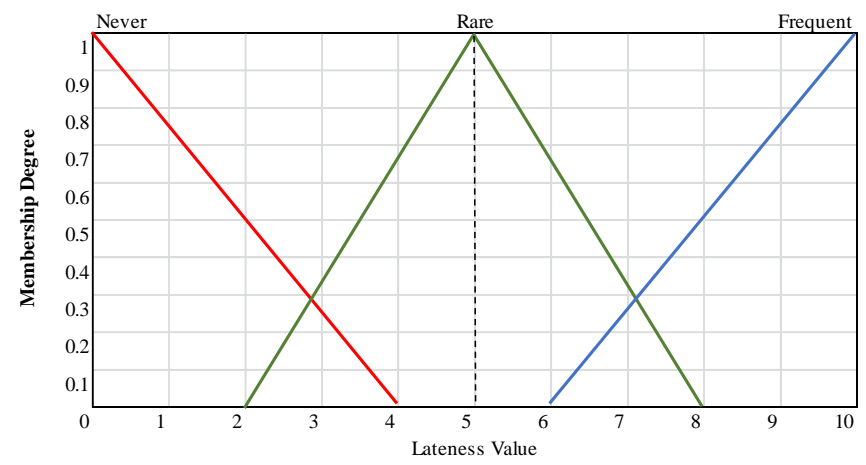

Fig. 4. MF Lateness.

In the Membership function of loyalty and responsibility, Fig. 2, the value of 0 to 4 categorized as low with the each of them has its own membership degree. Value of 0 has the membership degree of 1 ; Value of 4 has the membership degree of 0 . The value range of intermediate is 2 to 8 ; with the real intermediate is 5 . The value range of high category of loyalty and responsibility is 6 to 10; with the real high is 10 . The same mechanism is applied to the membership function of lateness and membership function of working speed as presented in Fig. 4 and 5 as well.

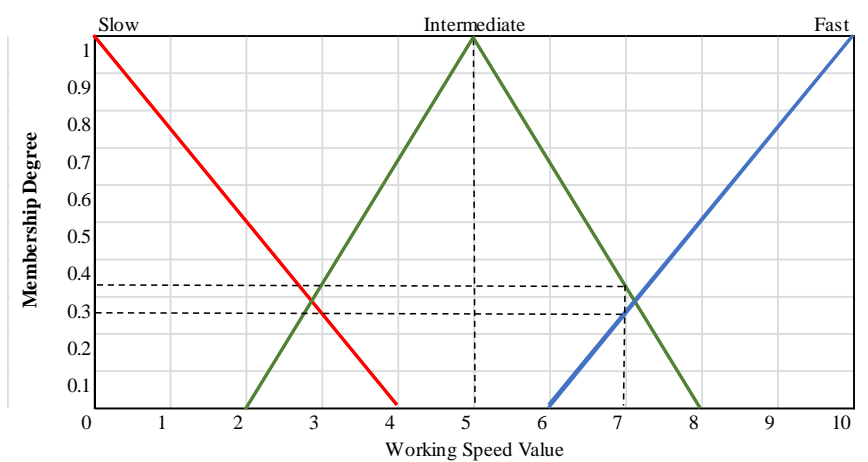

Fig. 5. MF Working Speed.

Fig. 6 presents the membership function of additional salary in percentage as the output. AS the management policy decision, its range is between $5 \%$ to $25 \%$. The low addition is $5 \%$, the standard is $15 \%$ and the high is $25 \%$.

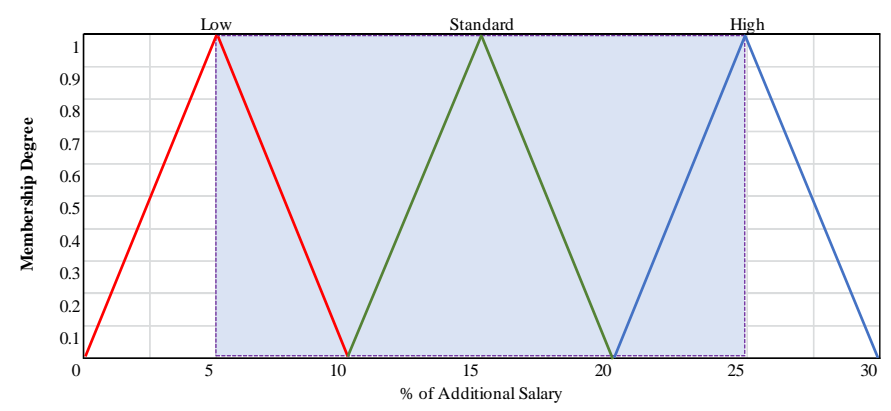

Fig. 6. MF Additional Salary.

\section{E. To Compute the Membership Value}

Refer to Table II, the example of the computation process in this case is the $6^{\text {th }}$ row (the grey block row). The membership value is computed as follows. Its loyaltyresponsibility, lateness, and working-speed value is 5, 5, and 7 as well. Fig. 7 presents the computational technique and its formula to obtain the membership degree value is presented in (1). Both of the loyatly-responsibility and lateness value is 5, thus it is clear that their membership value is intermediate and rare as well. Meanwhile the intermediate membership degree of the loyalty-responsibility is computed by applying the formula $f(x)=(x-a) /(b-a) \rightarrow f(x)=(5-2) /(5-$ $2)=1$. By applying the same formula to Latenes, the rare membership degree of lateness is 1 .

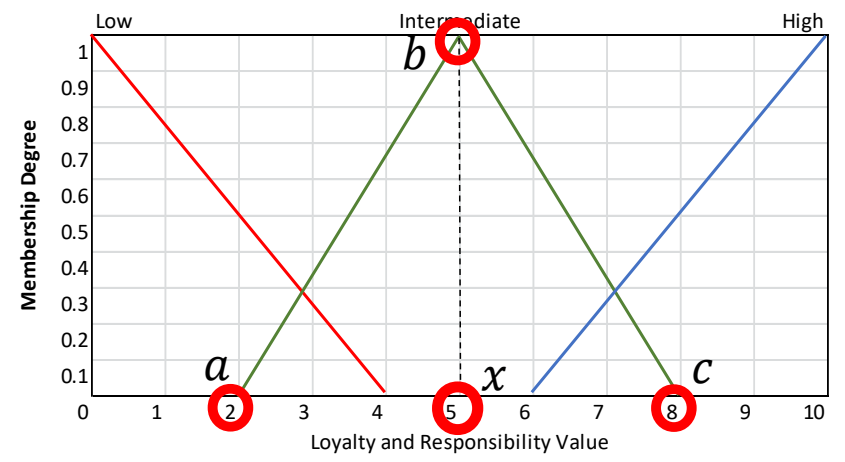

Fig. 7. Membership Value of Loyalty and Responsibilities. 


$$
f(x, a, b, c)=\left\{\begin{array}{c}
0, x \leq a \\
\frac{x-a}{b-a}, a \leq x \leq b \\
\frac{c-x}{c-b}, b \leq x \leq c \\
0, c \leq 0
\end{array}\right.
$$

It is a little bit difference in the membership value computation of working-speed. The value of working speed is 7 . As presented in fig 8 , the value crosses two category lines i.e. intermediate and fast. Therefor the membership degree of slow is 0 , whereas the membership degree of intermediate and fast is 0,25 and 0,33 bases on (2):

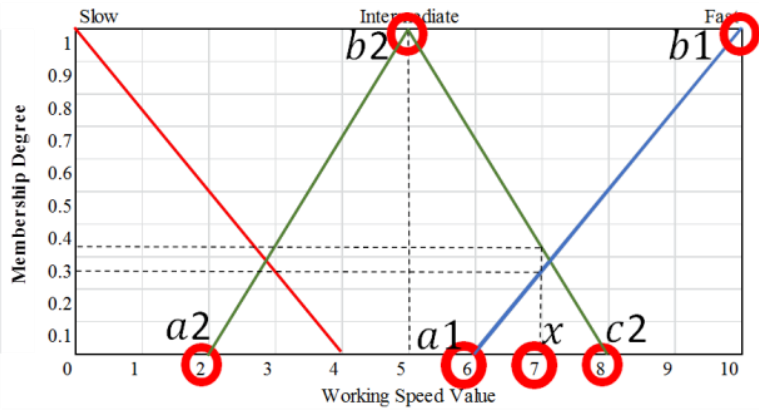

Fig. 8. Working Speed Membership.

$$
\begin{gathered}
f(x)_{\text {fast }}=\frac{x-a 1}{b 1-a 1} \\
f(x)_{\text {fast }}=\frac{7-6}{10-6}=0.25 \\
f(x)_{\text {intermediate }}=\frac{c 2-x}{c 2-b 2} \\
f(x)_{\text {intermediate }}=\frac{8-7}{8-5}=0.25
\end{gathered}
$$

The next step after the membership degree computation is the collection process of the computation results into a summary set as follows: Set Fuzzy loy_resp Low [5] = 0, Set. Fuzzy loy_resp intermediate [5] = 1, Set Fuzzy loy_resp High [5] = 0, Set Fuzzy late_never [5] = 0, Set Fuzzy late_rare [5] $=1$, Set Fuzzy late_frequent [5] = 0, Set Fuzzy work_speed slow [7] = 0, Set Fuzzy work_speed intermediate [7] = 0,33 , Set Fuzzy work_speed fast [7] = 0,25.

\section{F. To Apply the Fuzzy Operator}

There are two kinds of methods used to determine the fuzzy operator i.e. MAX (to take the maximum value) and MIN (to take the minimum value). The operator selection is based on the created rules. If the rule uses the OR operator, then the method to be used is MAX and if the rule uses the AND operator, then the method to be used is MIN. For this study, we define 27 rules. Some of those rules are listed below.

\section{Rule \#1}

IF Loy \& Resp. Low AND Lateness No AND Working Speed Slow THEN Additional Low $a_{1}=\min \left(\mu P \_\right.$Low [5], $\mu$ P_no [5], $\mu$ P_Slow [7]) $a_{1}=\min (0,0,0)=0$

\section{Rule \#14}

IF Loy \& Resp. Intermediate AND Lateness Rare AND Working Speed Intermediate THEN Additional Standard $a_{14}$

$=\min \left(\mu P_{\text {Intermediate }}[5], \mu P_{\text {_rare }}[5], \mu P_{\text {Intermediate }}[7]\right)$ $a_{1}=\min (\overline{1}, 1,0.33)=0.33$

\section{Rule \#27}

IF Loy \& Resp. High AND Lateness Frequent AND Working Speed Cepat THEN Additional Standard $a_{27}=\min \left(\mu P_{-}\right.$High [5], $\mu P_{\text {frequent }}[5], \mu P$ fast $\left.[7]\right)$ $a_{27}=\min (0,0,25)=0$

\section{G. To Apply the Implication Function}

The application of fuzzy rule provides the output value of 0.33 by rule \#14, 0.25 by rule \#15 and zeros by all other rules. Rule \#14 provide additional value categorized as low, whereas rule \#15 results categorized as high. Fig. 9 illustrates the mechanism in determining the value of crossing the line between the fuzzy rule and output variable.

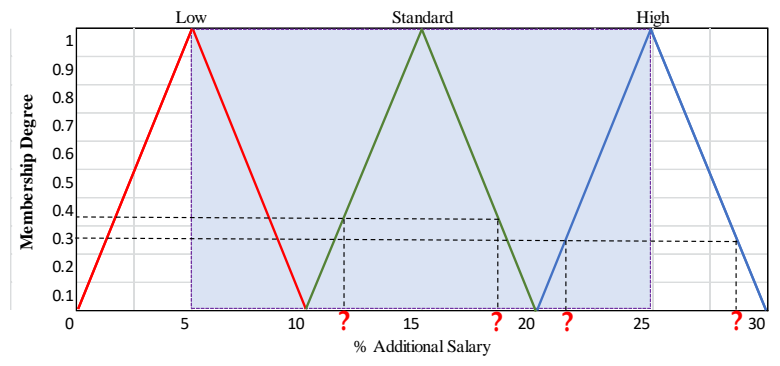

Fig. 9. Output Variable.

The crossing point is determined by the formula as follows:

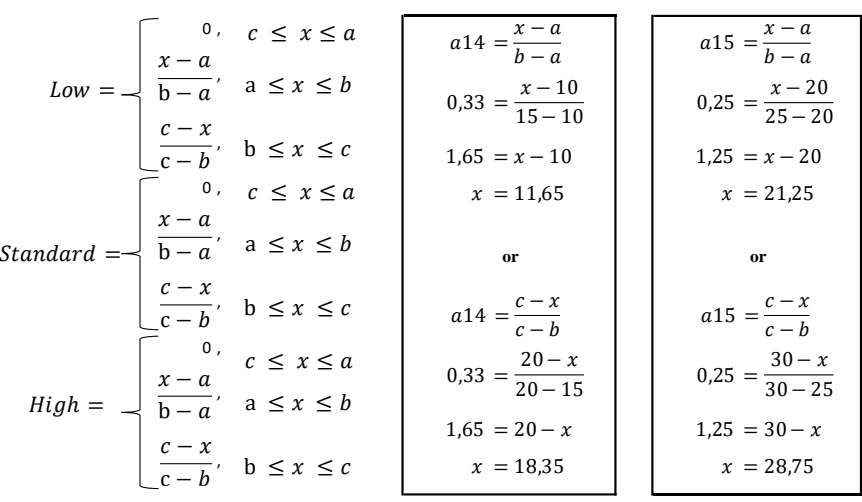

Following the formula, the crossing point value of area categorized as standard is 11.65 and 18.35 . Whereas the area categorized as high at 21.25 and 28.75 .

\section{H. Output Composition}

The computation and line determining process on output membership function provide trapezoidal regions called as the implication area. Both of trapezoidal regions cross the area that is categorized as standard and high as well. Fig. 10 presents the regions and the formula to compute its implication side. 

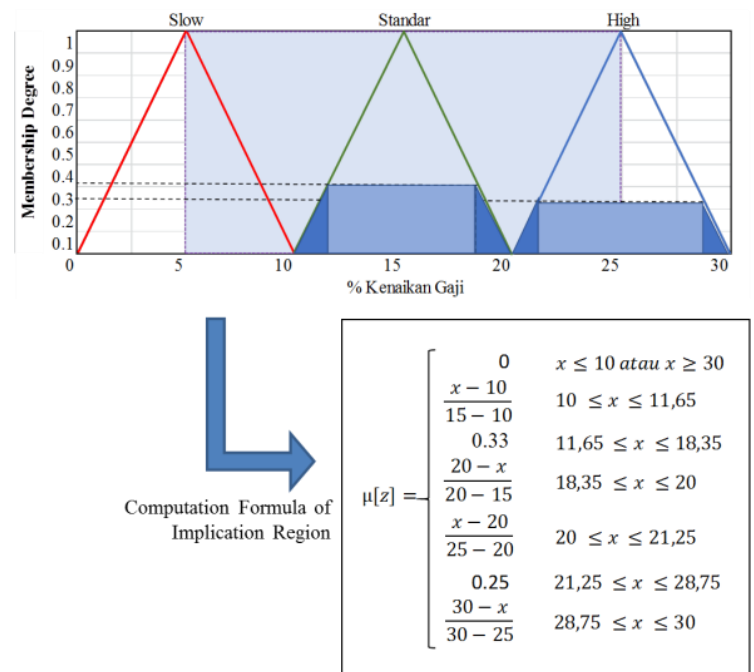

Fig. 10. Implication Region and Implication Function Formula.

\section{Defuzzyfication}

The method used to perform the defuzzyficatin process is the centroid method. The computation based on centroid method is performed by dividing the momen with the fuzzy wide area, as presented in Fig. 11.

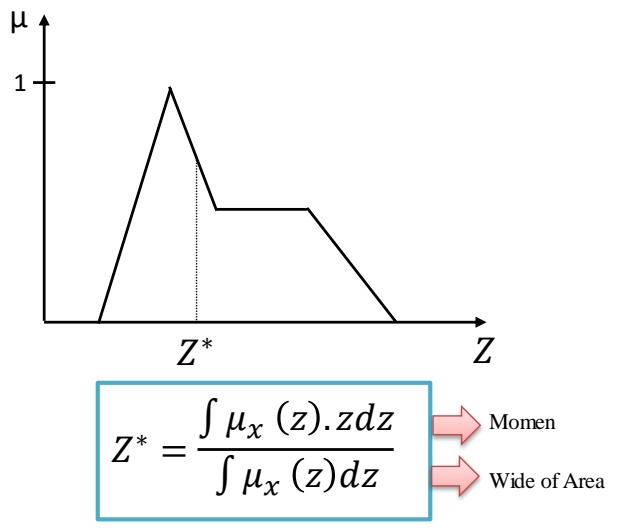

Fig. 11. Defuzzyfication Process.

\section{1) Moment Computation}

The value of the moment is computed from the previous implication region by applying the function integral to compute M1, M2, M3, M4, M5, M6. As an example, the integral application to compute M1 is:

$$
\begin{aligned}
\mathrm{M} 1= & \int_{10}^{11,65}(0,2 z-2) z d z \\
& \int_{10}^{11,65}\left(0,2 z^{2}-2 z\right) d z \\
& 0,0667 z^{3}-\left.z^{2}\right|_{10} ^{11,65} \\
& {\left[0,0667(11,65)^{3}-(11,65)^{2}\right]-\left[0,0667(10)^{3}-(10)^{2}\right] } \\
& {[105,464-135,723]-[66,7-100] } \\
& -30,259+33,3 \\
& 3,04
\end{aligned}
$$

All of the resulted moments are: $M_{1}=3,04 ; M_{2}=33,17$; $M_{3}=5,085 ; M_{4}=3,305 ; M_{5}=46,874 ; M_{1}=4,45$.

\section{2) Width of Area Computation}

The width of are computation is applied to six region components as presented in Fig. 12.

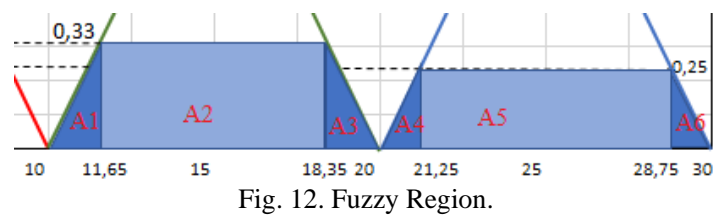

The next step is to compute the width of each area, as follows:

$$
\begin{aligned}
A 1 & =\frac{(11,65-10) * 0,33}{2}=0,27225 \\
A 2 & =(18,35-11,65) * 0,33=2,211 \\
A 3 & =\frac{(20-18,35) * 0,33}{2}=0,27225 \\
A 4 & =\frac{(21,25-20) * 0,25}{2}=0,15625 \\
A 5 & =(28,75-21,25) * 0,25=1,875 \\
A 6 & =\frac{(30-28,75) * 0,25}{2}=0,15625
\end{aligned}
$$

3) Centroid Computation

The centroid value is computed by to divide the moment by the width of the fuzzy region as follows:

$$
\begin{aligned}
& Z^{*}=\frac{(M 1+M 2+M 3+M 4+M 5+M 6)}{(A 1+A 2+A 3+A 4+A 5+A 6)} \\
& Z^{*}=\frac{(3,04+33,17+5,085+3,305+46,874+4,45)}{(0,27225+2,211+0,27225+0,15625+1,875+0,15625)} \\
& Z^{*}=\frac{95,924}{4,943} \\
& Z^{*}=19,406
\end{aligned}
$$

The centroid value is the final result represents the additional salary in percentage. For the sample above the employee whose loyalty $\&$ responsibility $=5$, Lateness $=5$ and working speed $=7$, will be awarded the additional salary of $19.41 \%$.

\section{RESUlTS AND DISCUSSION}

As described in the previous section, the dataset is collected from the real operation of Human Resources Department processes. Thus, the dataset has been used for the manual calculation before. The fuzzy computation results then are compared with the history of manual computation results. Table II presents a part of the comparation.

The manual computation only produces 3 kinds of additional salary values, i.e. $5 \%$ for low, $15 \%$ for standard, and 25 for high. This is caused by the computation is performed by HR staff who only predicts the value based on general rule. That's why the manual computation could not present the detail value as the fuzzy logic does. Even though there are some differences value of additional salary between that are provided manually and by fuzzy system, the deviation 
is not too significant. The deviation is ranging from 1.19$4.41 \%$. The less deviation confirms that the fuzzy logic is feasible to be applied for this purpose.

\begin{tabular}{cccccc}
\multicolumn{6}{c}{ TABLE II: RESULT COMPARISON OF MANUAL VS. FUZZY COMPUTATION } \\
\hline \hline & \multicolumn{5}{c}{ Attributes Value } \\
\cline { 2 - 6 } No & $\begin{array}{c}\text { Loy. } \\
\&\end{array}$ & Lateness & $\begin{array}{c}\text { Working } \\
\text { Speed }\end{array}$ & Manual & Fuzzy \\
& $\begin{array}{c}\text { Resp. } \\
\text { Rendional Salary }\end{array}$ & & & \\
\hline 1 & 9 & 2 & 3 & $25 \%$ & $20,59 \%$ \\
2 & 5 & 1 & 7 & $15 \%$ & $13,81 \%$ \\
3 & 7 & 2 & 6 & $15 \%$ & $13,81 \%$ \\
4 & 9 & 0 & 6 & $25 \%$ & $25 \%$ \\
5 & 3 & 9 & 4 & $5 \%$ & $5 \%$ \\
6 & 5 & 5 & 7 & $15 \%$ & $19,41 \%$ \\
7 & 6 & 2 & 5 & $5 \%$ & $5 \%$ \\
$\ldots$ &.. & $\ldots$ &. & $\ldots$ & $\ldots$ \\
56 & 8 & 7 & 7 & $15 \%$ & $19,41 \%$ \\
\hline
\end{tabular}

\section{CONCLUSION AND FUTURE WORK}

The study presents the results of fuzzy logic application to determine the additional salary, based on three employees attributes as the criteria. The experiment results confirm that the method is feasible to be used. The feasibility is proved by the less deviation - that can be tolerated- of manual computation results compared to the fuzzy system. In the future study, we will investigate the fuzzy logic to assist the 360 degree employee assessment to determine their career potentialities.

\section{REFERENCES}

[1] R. T. W. Evita, Siti Noni; Muizu, Wa Ode Zusnita; Atmojo, 'Penilaian kinerja karyawan dengan menggunakan metode behaviorally anchor rating scale dan management by objectives', Pekbis J., vol. 9, no. 1, pp. 18-32, 2017.

[2] R. Agusli, M. I. Dzulhaq, and U. Khasanah, 'Sistem Pendukung Keputusan Pemberian Bonus Karyawan Menggunakan Metode AHP', J. SISFOTEK Glob., vol. 7, no. 2, pp. 1-10, 2017.

[3] A. Shaout and M. Khalid Yousif, 'Employee Performance Appraisal System Using Fuzzy Logic', Int. J. Comput. Sci. Inf. Technol., vol. 6, no. 4, pp. 1-19, 2014.

[4] G. Meenakshi, 'Multi source feedback based performance appraisal system using Fuzzy logic decision support system', Int. J. Soft Comput. ( IJSC ), vol. 3, no. 1, pp. 91-106, 2012.

[5] M. G. D'Urso and D. Masi, 'Multi-Criteria Decision-Making Methods and Their Applications for Human Resources', in ISPRS International Archives of the Photogrammetry, Remote Sensing and Spatial Information Sciences, 2015, vol. XL-6/W1, no. June, pp. 3137.

[6] N. Shirinov, 'Application of Fuzzy Logic in Employee Promotion Decisions: Evidence from a Hypothetical Case', Acc. Financ. Manag. J., vol. 2, no. 4, pp. 630-634, 2017.

[7] K. M. Doka, F. Ahmad, S. Nor, and W. Shamsuddin, 'Integrated Decision Support System for Human Resource Selection Using TOPSIS Based Models', Appl. Math. Sci., vol. 9, no. 129, pp. 56-63, 2015.

[8] A. Muthohar, Y. Rahayu, J. T. Informatika, U. Dian, N. Semarang, and M. F. Mamdani, 'Metode Fuzzy Mamdani untuk Evaluasi Kinerja Pelayanan Perawat', J. Appl. Intell. Syst., vol. 1, no. 1, pp. 8-17, 2015.

[9] Syaeful Anas Aklani, 'Metode Fuzzy Logic Untuk Evaluasi Kinerja Pelayanan Perawat ( Studi Kasus : RSIA Siti Hawa Padang )', J. Edik Inform., vol. 1, no. 1, p. 30, 2014.

[10] M. L. Krichevsky, J. Martunova, and V. Sirotkin, 'Neuro-fuzzy recruitment system', Espacios, vol. 38, no. 62, p. 15, 2017.

[11] M. Tinkir, B. Doganalp, and S. Doganalp, 'Human Resource Selection Process by Using Various Fuzzy Logic Techniques Human Resource Selection Process by Using Various Fuzzy Logic Techniques', in Proceeding of the Workshop on Foundation of Informatics, 2015, no. December.

[12] Dedi, Prayogo, S. dul Hapid, and A. Mawardi, 'Sistem Pendukung Keputusan Penilaian Pegawai Dengan Menggunakan Logika Fuzzy',
J. SISFOTEK Glob., vol. 5, no. 1, 2015.

[13] A. A. Aguilar Lasserre, M. V. Lafarja Solabac, R. Hernandez-Torres, R. Posada-Gomez, U. Juarez-Martinez, and G. Fernandez Lambert, 'Expert System for Competences Evaluation 360 degrees Feedback Using Fuzzy Logic', Math. Probl. Eng., vol. 2014, 2014.

[14] E. Sakthivel, K. S. Kannan, and S. Arumugam, 'Optimized Evaluation of Students Performances Using Fuzzy Logic', Int. J. Sci. Eng. Res., vol. 4, no. 9, pp. 1128-1133, 2013.

[15] S. N. Ingoly and J. . Bakal, 'Evaluating Students' Performance using Fuzzy Logic', in International Conference in Recent Trends in Information Technology and Computer Science (ICRTITCS), 2012, pp. 15-20.

[16] S. Pavani, P. V. S. S. Gangadhar, and K. K. Gulhare, 'Evaluation of Teacher's Performance using Fuzzy Logic Techniques', Int. J. Comput. Trends Technol., vol. 3, no. 2, pp. 200-205, 2012.

[17] H. Aghajani, H. Nazoktabar, and A. Aliabadi, 'Environmental Performance Evaluation Based on Fuzzy Logic.', in International Proceedings on Scial Science and Humanity, 2011, vol. 5, pp. 432436.

[18] Yulmaini, 'Penggunaan Metode Fuzzy Inference System (Fis) Dalam Pemilihan Peminatan Mahasiswa Untuk Tugas Akhir', J. Inform., vol. 15 , no. $10721,2015$. 